\title{
PENGALAMAN MAHASISWA ILMU KEPERAWATAN STIKES CENDEKIA UTAMA KUDUS DALAM MELAKSANAKAN PEMBELAJARAN DARING SELAMA MASA PHYSICAL DISTANCING DI ERA PANDEMI COVID-19
}

\author{
Indah Apriliana*1, Gardha Rias Arsy ${ }^{2}$, Heriyanti Widyaningsih ${ }^{3}$ \\ ${ }^{1}$ Mahasiswa Prodi S1 Keperawatan, STIKES Cendekia Utama Kudus \\ ${ }^{2,3}$ Dosen Prodi S1 Keperawatan, STIKES Cendekia Utama Kudus
}

\section{${ }^{*}$ Correspondence: Gardha Rias Arsy}

Emali: gardarias051@gmail.com

\begin{abstract}
ABSTRAK
Pendahuluan: Coronavirus Disease 19 (COVID-19) merupakan penyakit yang menular yang di sebabkan oleh Coronavirus atau Severe Acute Respiratory Syndrom Coronavirus 2 (SarsCov2) yang menyerang pada sistem pernafasan dan berkembang sangat cepat. Physical Distancing salah satu upaya pemerintah untuk menekan angka penyebaran dan resiko kematian akibat COVID-19. Physical Distancing juga diterapkan di STIKES Cendekia Utama Kudus pada prodi S1 keperawatan dengan memberlakukan pembelajaran teori maupun praktik secara online atau daring.

Metode: Penelitian ini menggunakan jenis penelitian kualitatif dengan menggunakan pendekatan fenomenologi diskriptif melalui teknik wawancara mendalam. Partisipan dalam penelitian ini berjumlah 7 partisipan yang merupakan mahasiswa IImu Kepewaratan STIKES Cendekia Utama Kudus. Penelitian ini dilakukan bertujuan untuk mengetahui pengalaman mahasiswa keperawatan tentang pembelajaran secara daring selama masa pandemic Covid19.

Hasil: Hasil penelitian ini di dapat 4 tema yaitu (1) Ragam pengalaman mahasiswa selama pembelajaran daring di masa pandemi Covid-19 (2) Hambatan mahasiswa selama pembelajaran daring di masa pandemi Covid-19 (3) Kelebihan selama pembelajaran daring di masa pandemi Covid-19 (4) Peningkatan pembelajaran daring selama masa pandemi Covid-19.

Kesimpulan: Ragam pengalaman mahasiswa selama pembelajaran daring seperti jenuh, bosan, insomnia. Hambatan mahasiswa dalam pembelajaran daring selama masa pandemi Covid-19 seperti kendala sinyal dan ketidak efektifan dalam pemaparan materi. Kelebihan dalam pembelajaran daring pada masa pandemi Covid-19 seperti banyak mengenal teknologi dan aplikasi dan mempunyai banyak waktu dengan keluarga. Upaya peningkatan pembelajaran daring selama masa pandemi Covid-19 seperti praktik dilaksanakan offline, perkuliahan dilaksanakan secara tatap muka.
\end{abstract}

Kata Kunci: Covid-19; Physical Distancing, Pembelajarang Daring, Pandemi COVID-19.

\section{ABSTRACK}

Introduction: Coronavirus Disease 19 (COVID-19) is an infectious disease caused by Coronavirus or Severe Acute Respiratory Syndrome Coronavirus 2 (Sars-Cov2) which attacks the respiratory system and develops very quickly. Physical Distancing is one of the government's efforts to reduce the spread and risk of death due to COVID-19. Physical Distancing is also applied at STIKES Cendekia Utama Kudus in the undergraduate nursing study program by applying online or online theoretical and practical learning.

Metode: This study uses a qualitative type of research using a descriptive phenomenological approach through in-depth interview techniques. Participants in this study amounted to 7 participants who are students of Nursing Science STIKES Cendekia Utama Kudus. This 
study was conducted to determine the experiences of nursing students regarding online learning during the Covid19 pandemic.

Results: The results of this study obtained 4 themes, namely (1) Variety of student experiences during online learning during the Covid-19 pandemic (2) Student barriers during online learning during the Covid-19 pandemic (3) Advantages during online learning during the Covid-19 pandemic (4) Increased online learning during the Covid-19 pandemic.

Conclusion: Students' experiences during online learning are varied, such as boredom, boredom, insomnia. Barriers to students in online learning during the Covid-19 pandemic, such as signal constraints and ineffectiveness in presenting material. The advantages of online learning during the Covid-19 pandemic include knowing a lot about technology and applications and having a lot of time with family. Efforts to improve online learning during the Covid-19 pandemic, such as practice being carried out offline, lectures are carried out faceto-face.

\section{Keywords: Covid-19; Physical Distancing; Online Learning}

\section{PENDAHULUAN}

Pada awal bulan Februari Badan Nasional Penanggulangan Bencana menyebutkan di Indonesia ditemukan kasus pasien Covid sebanyak 1.223.930 kasus dengan angka kejadian meninggal sebesar 33.367 jiwa (BNPB, 2021). Sesuai laporan Satgas Covid Provinsi Jawa Tengah yang terbaru, terkonfirmasi terdapat 141.000 kasus pasien Covid 19 dengan angka kematian 5.924 Jiwa (BNPB, 2021) Saat ini kabupaten Kudus menjadi peringkat ke 2 kasus Covid 19 sebanyak 5215 pasien terkonfirmasi positif, dan dilaporkan 478 yang meninggal dunia. Adanya pandemi Covid 19 ini memberikan dampak yang luar biasa di segala aspek kehidupan masyarakat. Seperti halnya berimbas kepada pendidikan dan pelayanan (Satgas COVID-19, 2021). Akibat penyebaran wabah Covid-19 yang sangat cepat ini, maka setiap negara harus mempunyai tindakan atau cara untuk menekan angka penyebaran dari wabah Covid-19. Cara untuk menekan angka penyebaran yang di lakukan oleh pemerintah Indonesia sendiri yaitu membuat kebijakan dengan menerapkan protokol kesehatan yaitu dengan menjaga jarak (Physical Distancing), mencuci tangan, dan memakai masker. Selanjutnya menghindari aktivitas yang menimbulkan kerumunan, dengan tujuan agar tidak terjadi penyebaran virus Covid-19. Hal ini menyebabkan setiap orang diharuskan untuk mengurangi aktivitas diluar rumah, seperti bekerja, beribadah, dan termasuk belajar harus dilakukan di rumah untuk menghindari kontak fisik dengan orang lain (Kusumawati, 2020).

Kebijakan dalam penerapan Physical Distancing efektif dilakukan untuk mencegah penularan virus COVID-19 dan juga sudah mulai di laksanakan diberbagai wilayah di Indonesia, penerapan kebijakan ini merupakan salah satu upaya agar dapat menimbulkan berkurangnya produktivitas (Ahyar, 2002). Penerapan Physical Distancing yaitu dengan cara seperti tidak melakukan berpergian diluar rumah kecuali pada saat kondisi yang sangat diperlukan untuk keluar rumah, misalnya membeli kebutuhan pokok, atau berobat, menyapa orang lain dengan lambaian tangan. Usahakan jangan melakukan jabat tangan, hal ini guna untuk menghindari kontak fisik dengan orang lain. Semua kegiatan pembelajaran dan bekerja dilakukan dirumah (Ahyar, 2020). Pada bidang pendidikan sudah hampir satu tahun melaksanakan kegiatan pembelajaran daring, baik sekolah dini hingga mahasiwa Universitas dianjurkan untuk belajar dirumah (Suhandi, dkk, 2020). Sebelum terjadinya wabah COVID19. Pada dasarnya kegiatan pembelajaran di lakukan secara langsung atau tatap muka dalam satu ruangan atau kelas dimana pendidik dan peserta didik dapat berkomunikasi dan berinteraksi secara langsung. Tetapi sejak mengalami masa pandemi COVID-19 maka pembelajaran di lakukan dirumah secara daring (Conilie, 2020).

Kabar yang di lansir dari website resmi kemendikbud menjelaskan bahwa berdasarkan surat edaran dari Menteri Pendidikan dan Kebudayaan Nomor 36962/MPK.A/HK/2020 tertanggal 17 Maret 2020 tentang Pembelajaran secara daring dan bekerja dari rumah dalam rangka pencegahan penyebaran Corona Virus Disease (COVID-19) di masyarakat 
(Kemendikbud, 2020). Pembelajaran daring merupakan pembelajaran dalam jaringan yang menggunakan metode pembelajaran jarak jauh melalui aplikasi. Aplikasi yang digunakan telah di sepakati mahasiswa dan dosen selama pembelajaran daring berlangsung. Selain itu mahasiswa juga dapat mengunduh materi dan mengirimkan tugas melalui internet (Soegipranata, 2020). Aplikasi yang digunakan yaitu seperti whatsapp group, telegram, zoom meeting, google meet, google classroom dan aplikasi lainya (Wilson, 2020). Dalam pelaksanaanya sistem pembelajaran daring ini mempunyai kelebihan dan kekurangan tersendiri, dimana salah satu kelebihanya yaitu jadwal perkuliahan yang fleksibel, sedangkan salah satu kekurangannya yaitu kurang efektif dan optimal dalam penyampaian materi oleh dosen pengampu kepada mahasiswa (Aprilisanda, 2020).

Hal ini juga dapat dilihat dari banyaknya mahasiswa yang kesulitan memahami materi selama pembelajaran daring. Beberapa komentar dari mahasiswa bahwa perkuliahan daring ini menjadi hambatan bagi penyelenggara pendidikan baik itu institusi atau dosen dan mahasiswa (Argaheni, 2029). Hambatan yang terjadi yaitu seperti kendala dalam jaringan atau internet karena dalam pembelajaran daring harus membutuhkan layanan internet yang stabil ,dan mahalnya biaya pembelian kuota data internet untuk digunakan pada saat perkuliahan daring, belum lagi mata kuliah yang melakukan kuliah daring menggunakan aplikasi, maka akan sangat menguras kuota data baik bagi mahasiswa ataupun dosen (Khamida, dkk, 2020).Dampak kekurangan dari system pembelajaran daring itu bisa memberikan akibat atau dampak pada minat belajar mahasiswa, mahasiswa mulai jenuh dan bosan melakukan pembelajaran terhadap mata kuliah yang dipelajari pada saat masa pandemi ini, dan banyaknya beban tugas yang diberikan pada saat perkuliahan, dimana hal ini juga akan berakibat terhadap nilai yang akan diperoleh oleh mahasiswa. Belum lagi apabila system ujian akhir semester melelui system daring dengan kerumitan yang tinggi serta waktu yang sudah ditentukan akan sangat mempengaruhi minat belajar dan nilai mahasiswa (Widiyono, 2020).

Pada saat peneliti melakukan Studi Pendahuluan di STIKES Cendekia Utama Kudus kepada Mahasiswa Prodi IImu Keperawatan di dapatkan hasil bahwa mahasiswa kurang memahami materi yang di sampaikan dari dosen. Hal itu dikarenakan ilmu keperawatan terdapat materi praktikum yang tidak bisa hanya di sampaikan melalui daring atau tidak secara tatap muka. Selain itu mahasiwa juga mengeluh tentang kesulitan sinyal saat pembelajaran daring dan akan berakibat susah dalam mendownload materi yang di berikan dari dosen. Mahasiwa juga mengeluh selama pembelajaran daring pengeluaran pembelian kuota data internet sangat boros. Keadaan tersebut terjadi karena pada proses pembelajaran daring beberapa dosen menghendaki pemakaian aplikasi seperti Zoom atau Google Meet. Tidak hanya itu, mahasiswa Ilmu Keperawatan juga mengeluh tentang banyaknya tugas yang diberikan secara terus menerus dengan deadline yang cepat membuat mahasiswa menjadi lelah, bosan dan insomnia. Mahasiswa juga mengeluh selama masa pembelajaran daring, tidak bisa lepas dari gadget karena ditakutkan jika terlambat dalam absen maka dianggap tidak mengikuti perkuliahan tersebut.

Hal positif yang di alami dalam pembelajaran daring dari mahasiswa IImu Keperawatan STIKES Cendekia Utama Kudus adalah mereka merasa lebih kreatif dalam mencari materi pemebelajaran, pembelajaran daring bisa dilakukan di mana saja, selain itu mahasiswa mengatakan bahwa selama pembelajaran daring menjadi lebih hemat dalam pengeluaran uang saku. Selain hasil wawancara dengan beberapa mahasiswa, peneliti juga melihat aktivitas di sosial media dimana topic yang saat ini sedang trending dibicarakan adalah "Kuota Sekarat IImu tak Dapat". Dari topik tersebut membuktikan bahwa keadaan yang di alami oleh mahasiswa berbanding lurus dengan data awal peneliti, dimana mahasiswa lebih banyak diberikan tugas. Tujuan dari penelitian ini adalah (1) Untuk mengetahui secara mendalam Pengalaman Mahasiswa IImu Keperawatan STIKES Cendekia Utama Kudus dalam Pembelajaran Daring Selama Masa Physical Distancing di Era Pandemi COVID-19 (2) Untuk mengetahui Pengalaman Mahasiswa IImu Keperawatan STIKES Cendekia Utama Kudus dalam Pembelajaran Daring Selama Masa Physical Distancing di Era Pandemi 
COVID-19 (3) Untuk mengetahui support sistem pada mahasiswa IImu Keperawatan STIKES Cendekia Utama Kudus dalam pembelajaran daring selama masa Physical Distancing di era pandemi COVID-19. Oleh karena itu berdasarka penjelasan data diatas peneliti tertarik untuk mendiskripsikan persepsi dan pandangan mahasiswa IImu Keperawatan STIKES Cendekia Utama Kudus berdasarkan pengalamanya dalam pembelajaran daring selama masa Physical Distancing di era pandemi Covid-19.

\section{METODE}

Penelitian ini menggunakan metode kualitatif. Penelitian ini bertujuan untuk mendiskusikan yang terjadi dan di alami oleh partisipan selama pembelajaran daring dimasa pandemic Covid-19 melalui proses penelitian secara menyeluruh serta terperinci meliputi : apa saja yang terjadi, bagaimana bisa terjadi dan mengapa hal tersebut dapat terjadi. Pada penelitian kualitatif ini, terdapat proses komunikasi dan interaksi antara peneliti dan partisipan. Subjek dan objek yang dipilih peneliti sebagai partisipan adalah mahasiswa STIKES Cendekia Utama Kudus. Mahasiswa STIKES Cendekia Utama Kudus prodi IImu Keperawatan, semester 2, 4, dan 6, yang mengalami pengalaman pembelajaran daring, bersedia menjadi partisipan, bersedia di wawancarai dan direkam selama proses penelitian

Teknik pengumpulan data menggunakan prosedur teknik wawancara (indepth interview) dengan menggunakan panduan pertanyaan semi terstruktur, field note atau catatan lapangan dengan tujuan melihat respon non verbal dari partisipan serta situasi saat proses pelaksanaan wawancara pada partisipan. Tahapan dalam pengumpulan data yaitu (1) prosedur administrative (2) prosedur teknis. Proses analisa data dalam penelitian kualitatif dilaksanakan secara terus menerus dan secara interaktif hingga tuntas, dan mencapai data jenuh. Penelitian kualitatif ini menggunakan analisa data yang telah dikemukakan oleh Smith, et, al., (2009) yaitu Interpretative Phenomenological Analysis (IPA). Mengguankan IPA dalam menganalisis data bertujuan untuk dapat memahami suatu peristiwa dari sudut pandang partisipan. Adapun tahapan pelaksanaan dalam Interpretative Phenomenological Analysisa antara lain: 1) Reading and re-reading ; 2) Initial noting; 3) Developing emergent themes; 4) Searching for connection across emergent themes; 5)Moving the next cases; 6) Looking for patterns across cases; 7) Taking interpretation to deeper levels

\section{HASIL}

Berdasarkan hasil wawancara yang dilakukan peneliti tentang Pengalaman Mahasiswa IImu Keperawatan STIKES Cendekia Utama Kudus Dalam Melaksanakan Pembelajaran Daring Selama Masa Physical Distancing di Era Pandemi COVID-19, peneliti mengidentifikasikan uraian hasil wawancara tersebut dalam 4 tema utama yaitu (1) Ragam perasaan mahasiswa S1 IImu Keperawatan STIKES Cendekia Utama Kudus dalam pembelajaran daring, (2) Hambatan mahasiswa selama pembelajaran daring di masa pandemi Covid-19 (3) Kelebihan selama pembelajaran daring di masa pandemi Covid-19, (4) Upaya peningkatan pembelajaran daring selama masa pandemi Covid-19. Tema yang dihasilkan dalam penelitian ini di bahas secara terpisah, tetapi tema-tema tersebut saling berhubungan satu sama lain untuk menjelaskan esensi Pengalaman Mahasiswa Ilmu Keperawatan STIKES Cendekia Utama Kudus Dalam Melaksanakan Pembelajaran Daring Selama Masa Physical Distancing di Era Pandemi COVID-19.

\section{Tema 1: Ragam Pengalaman mahasiswa selama pembelajaran daring di masa pandemi Covid-19.}

Tema ini memberikan gambaran pengalaman mahasiswa selama pembelajaran daring di masa pandemi Covid-19. Menurut KBBI (2020) kata pengalaman mempunyai arti yang pernah di alami atau dijalani. Tema yang di dapat tersebut berdasarkan sub-sub tema yang membangun dari tema tersebut. Sub tema tersebut yaitu merasa bosan selama pembelajaran daring, merasa jenuh selama pembelajaran daring, mengalami insomnia selama pembelajaran daring. 


\section{Merasa bosan selama pembelajaran daring}

Selama pembelajaran daring di masa pandemi Covid-19, para partisipan memberikan respon berbeda. Tetapi banyak partisipan yang mengeluh bosan dan jenuh. Selama pembelajaran daring di masa pandemi Covid-19. Menurut KBBI (2021) kata bosan memiliki arti sudah tidak suka lagi karena sudah terlalu sering atau terlalu banyak. Berikut contoh kutipan ungkapan partisipan:

“...kok gini banget ya...kuliah gini-gini aja, di WA, di google meet, classroom, jadi kalo males di dengerin aja mbak, video nya ya engga di tonton..." (P1)

“...kadang bosen, tidak bisa bertemu dengan teman-teman..." (P2)

"... sedih, bosen mbak, tidak ada teman secara langsung..." (P4)

"...dirumah membosankan, suasana belajar berbeda tidak seperti saat perkuliahan tatap muka.." (P5)

"...yang saya rasakan selama satu tahun kuliah daring ini saya merasa bosan mbak, jenuh, kurang maksimal penyampaian materi dari dosen kepada mahasiswa..." (P6)

"...saya sudah bosan mbak, kadang juga malas mengikuti pembelajaran,jadi ya cuma absen saja tapi tidak mengikuti..."(sambil tersenyum malu) (P7)

\section{Merasa jenuh selama pembelajaran daring}

Selain itu partisipan kedua, keempat, keeenam, juga mengatakan bahwa pengalaman pembelajaran daring membuat jenuh. Menurut KBBI (2021) jenuh mempunyai arti jemu atau sudah jenuh dengan pekerjaan yang selalu sama dilakukan sepanjang tahun. Berikut contoh ungkapan partisipan:

“...kadang juga jenuh mbak perkuliahan seperti ini...” (P2)

"...duh mbak tugasnya numpuk terus, tidak sempet liburan, dalam satu hari kadang ada tiga tugas yang dikumpulkan kadang malah lebih..." (p4)

"...yang saya rasakan selama satu tahun kuliah daring saya merasa bosan, jenuh sekali mbak..." (P6)

\section{Mengalami insomnia selama pembelajaran daring}

Selain itu juga partisipan ketiga, keempat, kelima, ketujuh mengatakan bahwa pembelajaran daring membuat insomnia. Menurut KBBI (2021) insomnia memiliki arti keadaan tidak dapat tidur. Berikut contoh kutipan ungkapan dari partisipan:

“... bahkan saya sampai insomnia mengerjakanya hingga larut malam..." (P3)

"...saya kalau tugas belum selesai tidak bisa tidur dan kepikiran terus kak..." (P4)

"...tidak bisa tidur, sering insomnia karena banyak tugas-tugas yang harus dikerjakan dan deadline mepet sekali..." (P5)

"...saya lebih sering beraktivitas malam hari, disitu saya mengerjakan tugas sampai begadang mengerjakan tugas itu kak..." (P7)

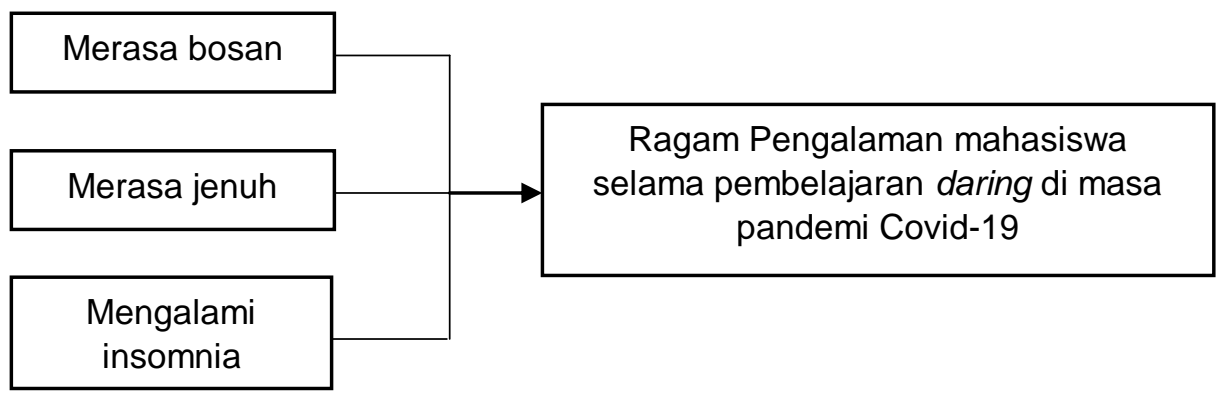

\section{PEMBAHASAN}

Berdasarkan hasil penelitianterkait dengan ragam pengalaman mahasiswa selama pembelajaran daring di masa pandemic Covid 19, wawancara menunjukkan bahwa semua partisipan mengalami berbagai pengalaman yang menunjukkan perasaanya selama pembelajaran daring. Diantaranya rasa bosan, jenuh dan insomnia. Hal tersebut sesuai 
dengan penelitian yang dilakukan oleh Conilie (2020) dalam penelitianya tentang analisis pembelajaran daring terhadap kejenuhan mahasiswa mengatakan bahwa mahasiswa mengalami kelelahan emosi seperti stress, jenuh, bosen akibat tekanan selama pembelajaran daring. Hal ini justru membuat mahasiswa menjadi tidak fokus dan kehilangan konsentrasi saat pembelajaran daring. Hasil penelitian tersebut selaras dengan penelitian Kusnayat, dkk (2020) dalam penelitianya tentang pengaruh pembelajaran kuliah online di era covid 19 dan dampak terhadap mental mahasiswa mengatakan bahwa mahasiswa mengalami insomnia atau kesulitan tidur akibat tekanan tugas, selain itu mahasiswa mengalami stress akibat pembelajaran daring di era pandemi ini. Sesuai penyataan Djayadin dkk (2020) dimana peneliti meneliti tentang analisis asesmen diagnostik pada konsentrasi mahasiswa selama pembeljaran daring mengatakan bahwa mahasiswa banyak yang mengalami jenuh dan bosan pada saat mengikuti pembelajaran daring hal ini dapat mengakibatkan mahasiswa mengalami ketidak stabilan emosi, padahal kestabilan emosi sangat berperan penting terhadap keberhasilan belajar seseorang. Keadaan tersebut juga diperkuat dengan penelitian Djayadin dkk (2020) bahwa 73,1\% mahasiswa mengalami rasa jenuh dan bosan saat mengikuti pembelajaran daring.

Berdasarkan hasil penelitian untuk hambatan mahasiswa selama pembelajaran daring di masa pandemic Covid 19, partisipan banyak mengalami berbagai hambatan selama pembelajaran daring seperti mengalamai kendala sinyal dan susah untuk memahami materi yang disampaikan dari dosen. Seperti yang ada di disampaikan Hidayat (2020) tentang penelitianya yang berjudul pengalaman mahasiswa saat kelas online menyatakan bahwa salah satu masalah dalam pembelajaran online yaitu kendala di jaringan internet yang tidak stabil atau buruk, karena tidak semua tempat atau daerah tersedia jaringan internet. Hal ini menjadikan salah satu hal kendala mahasiswa dalam pembelajaran daring di masa pandemi Covid 19 saat ini. Hal tersebut sejalan dengan penelitian yang dilakukan oleh Paujiah (2020) dalam penelitianya yang berjudul hambatan pembelajaran daring di masa pandemi Covid 19 mengatakan bahwa pembelajaran daring membuat mahasiswa merasa sulit untuk memahami materi perkuliahan, pemaparan materi kurang efektif, sehingga membuat mahasiswa menjadi susah untuk memahami materi perkuliahan online. Selain itu hambatan lainya dalam pembelajaran daring yaitu kendala sinyal, hal ini mengakibatkan pembelajaran online dan pemaparan materi yang disampaikan oleh dosen kurang efektif.

Menurut Syafrillia, dkk (2020) dalam penelitianya yang berjudul analisis kendala pemahaman teknologi kuliah daring mahasiswa pada masa pandemi Covid-19 mengatakan bahwa kendala yang banyak dialami mahasiswa umumnya adalah di jaringan internet dan pada proses pemahaman materi selama pembelajaran daring. Sebanyak $75 \%$ siswa mengalami kendala kurangnya memahami materi selama pembelajaran online. Hal tersebut juga sesuai dengan penelitian Gultom dkk ( 2021) yang berjudul pengalaman mahasiswa pendidikan ners dalam pembelajaran daring yaitu bahwa kendala atau hambatan yang dirasakan mahasiswa dalam pembelajaran daring yaitu pelaksanaan pembelajaran daring tidak efektif, terutama daam pemaparan materi yang disampaikan dari dosen menjadi susah atau kurang bisa dipahami. Berdasarakan hasil penelitian yang dikakukan oleh Muthmainnah dkk (2021) dalam penelitianya yang berjudul pengalaman mahasiswa keperawatan tentang pembelajaran daring dalam situasi penyakit Covid-19 tahun 2020 mengatakan bahwa hambatan yang ditemui selama proses pembelajaran daring yaitu susah sinyal atau jaringan sehingga tidak mengerti dengan penjelasan dosen hal ini dikarenakan jaringan internet yang belum merata di seluruh wilayah Indonesia, listrik mati, dan cuaca buruk seperti hujan dan petir sehingga menyebabkan tidak bisa terkoneksi dengan pembelajaran dan biaya internet yang mahal juga menjadi hambatan dalam pembelajaran daring.

Hasil penelitian terkait dengan kelebihan pembelajaran daring pada masa pandemic Covid 19. Pengalaman mahasiswa selama pembelajaran daring mempunyai banyak kelebihan yaitu bisa banyak mengenal teknologi dan aplikasi dan mempunyai banyak waktu dengan keluarga. Hal tersebut sesuai dalam penelitian Pakpahan (2020) yang berjudul analisa pemanfaatan teknologi informasi dalam pembelajaran daring di tengah pandemi 
mengatakan bahwa pembelajaran daring atau pembelajaran jarauk jauh mempunyai kelebihan yaitu untuk memenuhi standart pendidikan dengan pemanfaatan teknologiteknologi yang modern. Selama pembelajaran daring ini mahasiswa menjadi lebih aktif dan lebih mengenal teknologi-teknologi yang baru. Hal tersebut juga selaras dengan penelitian Ningsih (2020) dalam penelitianya yang berjudul persepsi mahasiswa terhadap pembelajaran daring pada masa pandemi Covid-19 mengatakan bahwa mahasiswa dapat meluangkan waktu lebih bersama keluarga karena dalam pembelajaran online bahan perkuliahan yang diberikan data diakses mahasiswa dengan cara mengunduh materi dimana saja, kapan saja tanpa di batasi ruang dan waktu. Berdasarkan penelitian yang dilakukan oleh Andini (2020) yang berjudul dampak pembelajaran daring bagi mahasiswa di masa pandemi Covid-19 mengatakan bahwa kelebihan dalam pembelajaran daring dapat melakukan pembelajaran dirumah dengan santai dan bisa berkumpul dengan keluarga, dapat mengakses materi pembelajaran daring kapan saja dan dapat membuka materi dengan mudah. Selain itu mahasiswa maupun dosen dapat mengenal dan memanfaatkan aplikasi aplikasi yang baru. Menurut penelitian Gultom dkk ( 2021) dalam penelitianya yang berjudul pengalaman mahasiswa pendidikan ners dalam pembelajaran daring mengatakan bahwa pembelajaran daring adalah kegiatan belajar lebih fleksibel dan rileks, karena pembelajaran daring dapat dilakukan dimana saja, kapan saja, dan pelaksanaanya santai tidak terburu-buru.

Hasil penelitian terkait upaya peningkatan pembelajaran daring selama masa pandemic Covid 19. Dalam penelitian ini mahasiswa menunjukan bahwa banyak harapan dari pembelajaran daring salah satunya pembelajaran praktik atau skill lab yang harus di lakukan secara offline atau tatap muka. Hal ini sesuai dalam penelitian Widiyono (2020) yang berjudul efektifitas perkuliahan daring (online) pada mahasiswa di saat pandemi Covid-19 yang mengatakan bahwa mahasiswa menginginkan perkuliahan secara luring dan siap mengahapi aturan baru dengan memperhatikan prinsip protocol kesehatan. Menurut penelitian yang dilakukan pattahh (2020) yang berjudul pengalaman mahasiswa ilmu keperawatan universitas hasanuddin dalam melaksanakan pembelajaran daring selama masa pandemi Covid-19 mengatakan bahwa perlu upaya untuk meningkatkan kualitas pembelajaran daring supaya dapat telaksana dengan baik dan dapat meningkatkan minat mahasiswa dalam pembelajaran daring. hal tersebut juga di perjelas dalam penelitian Ningsih (2020) yang berjudul persepsi mahasiswa terhadap pembelajaran daring pada masa pandemi Covid-19 mengatakan bahwa 93,5\% lebih menyukai pembelajaran offline dikelas secara tatap muka dibandingkan dengan pembelajaran daring. Hal ini juga disampaikan oleh Iskandar (2020) dalam penelitianya yang menyatakan bahwa 56\% mahasiswa tidak senang pekuliahan dengan sistem daring, dan $43,4 \%$ senang dengan perkuliahan dengan sistem daring.

\section{SIMPULAN}

Hasil kesimpulan dari penelitian Pengalaman Mahasiswa IImu Keperawatan STIKES Cendekia Utama Kudus dalam Melaksanakan Pembelajaran Daring Selama Masa Physical Distancing di Era Pandemi Covid-19, yang telah melibatkan tujuh partisipan dapat disimpulkan menjadi 4 tema yaitu (1) Ragam pengalaman mahasiswa selama pembelajaran daring, (2) Hambatan mahasiswa dalam pembelajaran daring di masa pandemi Covid-19, (3) Kelebihan pembelajaran daring selama masa pandemi Covid-19, (4) Upaya peningkatan pembelajaran daring selama masa pandemi Covid-19. Ragam pengalaman mahasiswa selama pembelajaran daring seperti jenuh, bosan, insomnia. Hambatan mahasiswa dalam pembelajaran daring selama masa pandemi Covid-19 seperti kendala sinyal dan ketidak efektifan dalam pemaparan materi. Kelebihan dalam pembelajaran daring pada masa pandemi Covid-19 seperti banyak mengenal teknologi dan aplikasi dan mempunyai banyak waktu dengan keluarga. Upaya peningkatan pembelajaran daring selama masa pandemi Covid-19 seperti praktik dilaksanakan offline, perkuliahan dilaksanakan secara tatap muka. 


\section{DAFTAR PUSTAKA}

Abdul Rahman, Agus, (2016) Metodelogi Penelitian Psikologi Langkah Cerdas Menyelesaikan Skripsi, Bandung : PT Remaja Rosdakarya.

Ahmadi, Rulam. 2016. Metodelogi Penelitian Kualitatif. Yogjakarta: Ar-Ruzz Media

Andiarna, F., \& Kusumawati, E. (2020). Pengaruh Pembelajaran Daring Terhadap Stres Akademik Mahasiswa Selama Pandemi Covid-19. Jurnal Psikologi, 16(2), 139-149.

Andini, N. F. (2020). Dampak Pembelajaran Daring Bagi Mahasiswa Masa Pandemi Covid19. Academia. Edu.

Creswell, 2014. Risearch Design: Pendekatan Kualitatif, Kuantitatif, dan Mixed, Yogyakarta: Gadjah Mada University.

Fitriani, W., Haryanto, H., \& Atmojo, S. E. (2020) Motivasi Berprestasi dan Kemandirian Belajar Mahasiswa saat Pembelajaran Daring. Jurnal Pendidikan: Teori, Penellitian, dan Pengembangan, 5(6), 824-834.

Fitriasari, A., Septianingrum, Y., \& Budury, S. (2020). Stress Pembelajaran Online Berhubungan Dengan Strategi Koping Mahasiswa Selama Pandemi Covid-19. Jurnal Keperawatan, 12(4), 985-992

Gultom, R. F. N., \& Tambunan, E. H. (2021). Pengalaman Mahasiswa Program Studi Pendidikan Ners Dalam Pembelajaran Daring Di Masa Pandemi Covid-19. Nursing Update: Jurnal IImiah IImu Keperawatan P-ISSN: 2085-5931 e-ISSN: 2623-2871, 12(1), 12-21.

Hasanah, A., Lestari, A. S., Rahman, A.Y., \& Daniel, Y. I (2020). Analisis aktivitas belajar daring mahasiswa pada pandemi Covid-19

hifzul Muiz, M., \& Sumarni, N. (2020). Pengaruh Teknologi Pembelajaran Kuliah Online Di Era Covid-19 Dan Dampaknya Terhadap Mental Mahasiswa. EduTeach: Jurnal Edukasi Dan Teknologi Pembelajaran, 1(2), 153-165

Jamaluddin, D., Ratnasih, T., gunawan, h., \& Paujiah, E. (2020). Pembelajaran daring masa pandemi Covid-19 pada calon guru: hambatan, solusi dan proyeksi. LP2M.

Jamil, S. H., \& Aprilisanda, I. D. (2020). Pengaruh Pembelajaran daring terhadap minat belajar mahasiswa pada masa pandemik covid-19. Behavioral Accounting Journal, 3(1), 37-46.

Kementrian Kesehatan Republik Indonesia. (2020). Kesiapsiagaan Menghadapi Infeksi COVID-19. Diakses dari https://www.kemkes.go.id/ pada tanggal 10 Januari 2021

Kementrian Kesehatan Republik Indonesia. 2020. Apa yang Harus di Lakukan Masyarakat Untuk cegah Penularan COVID-19?. Jakarta: Kementrian Kesehatan Republik Indonesia.

Kementrian Kesehatan Republik Indonesia. 2020. Pedoman Pencegahan dan Pengendalian Coronavirus Disease (COVID-19). Jakarta: Kementrian Kesehatan Republik Indonesia

Keputusan Menteri Kesehatan Republik Indonesia. (2020). Keputusan Menteri Kesehatan Republik Indonesia Nomor HK.01 .07/MenKes/413/2020 Tentang Pedoman Pencegahan dan pengendalian Corona Virus Disea2se 2019 (Covid-19). MenKes/4132/2020,2019,207.

Moleong , Lexy J. (2012). Metodelogi Penelitian Kualitatif. Bandung : PT Remaja Rosdakarya.

Murni, I., Dasar, P. P., Pascasarjana, P., Negeri, U., Murni, I., Dasar, P. P., Pascasarjana, P., \& Negeri, U. (2019). Fase dan tugas perkembangan anak sekolah dasar. VII(1), $51-59$

Muthmainnah, M., \& Ananda, Y. (2021). Studi Fenomenologi: Pengalaman Mahasiswa Keperawatan Tentang Pembelajaran Daring dalam Situasi Penyakit COVID-19 Tahun 2020. JIK (Jurnal Ilmu Kesehatan), 5(1), 33-38.

Ningsih, S. (2020). Persepsi Mahasiswa Terhadap Pembelajaran Daring Pada Masa Pandemi Covid-19. JINOTEP (Jurnal Inovasi Dan Teknologi Pembelajaran): Kajian Dan Riset Dalam Teknologi Pembelajaran, 7(2), 124-132. 
Notoatmodjo, Soekidjo. 2012. Promosi Kesehatan dan Perilaku Kesehatan. Jakarta : Rineka cipta.

Nursalam. (2011). Konsep dan Penerapan Metodelogi Penelitian IImu Keperawatan. Jakarta : Salemba Medika.

Otálora, M. M. C. (2020). Yuliana. Parque de Los Afectos. Jóvenes Que Cuentan, 2(February), 124-137.

Paru, K. T., Malang, S., Pemberian, P., Terhadap, V. C., Foto, P., Pada, T., \& Tuberkulosis, P. (2019). Multi-Drug Resistance Tuberculosis : 40(2)

PATTAAH, A. N. (2020). PENGALAMAN MAHASISWA ILMU KEPERAWATAN UNIVERSITAS HASANUDDIN DALAM MELAKSANAKAN PEMBELAJARAN DARING

SELAMA MASA PANDEMI COVID19 (Doctoral dissertation, Universitas Hasanuddin).

Pawicara, R., \& Conilie, M.(2020). Analisis Pembelajaran Daring terhadap Kejenuhan Belajar Mahasiswa Tadris Biologi IAIN Jember di Tengah Pandemi Covid-19. ALVEOLI:Jurnal Pendidikan Biologi

Polit \& Beck. (2012). Resource Manual for Nursing Research. Generating and Assesing evidence for Nursing Practice. Ninth edition. USA : Lippincott.

Saparwati, M. (2012). Studi Fenomenologi : Pengalaman Kepala Ruang Dalam Mengelola Ruang Rawat Inap di RSUD Ambarawa. Jurnal Gizi dan Kesehatan Vol 4 (2), 71-78.

Semiawan Conny, R (2010). Metode Penelitian Kualitatif. Jakarta: Grasindo.

Smith, J.A., et al. (2009). Interperetative Phenomenological analysis-theory, method, and research. London, UK: Sage Publications.

Sriyanti, L. 2014. Psikologi Belajar. Jakarta.

Sujarweni, V. Wiratna. 2014. Metode Penelitian: Lengkap, Praktis, dan Mudah Dipahami. Yogyakarta: pustaka Baru Press.

Supariasa, I.D.N. dkk. 2013. Penelitian Status Gizi (Edisi Revisi). Jakarta: Penerbit Buku Kedokteran EGC

Susilo, A., Rumende, C. M., Pitoyo, C. W., Santoso, W. D., Yulianti, M., Sinto, R., Singh, G., Nainggolan, L., Nelwan, E. J., Khie, L., Widhani, A., Wijaya, E., Wicaksana, B., Maksum, M., Annisa, F., Jasirwan, O. M., Yunihastuti, E., Penanganan, T., New, I., ... Cipto, R. (2020). Coronavirus Disease 2019: Tinjauan Literatur Terkini Coronavirus Disease 2019: Review of Current Literatures. 7(1), 45-67.

Widiyono, A. (2020). Efektifitas perkuliahan daring (online) pada mahasiswa pgsd di saat pandemi covid 19. Jurnal Pendidikan, 8(2), 169-177.

World Health Organization. Laboratory testing for coronavirus disease 2019 (COVID-19) in suspected human cases. Geneva: World Health Organization

World Health Organization. Infection prevention and control during health care when novel coronavirus (nCoV) infection is suspected. Geneva: World Health Organization; 2020

World Health Organization. Critical Preparedness, readiness and response actions for COVID-19. Geneva: World Health Organization; 2020

World Health Organization. Rational use of personal protective equipment for coronavirus disease (COVID-19). Geneva: World Health Organization; 2020.

World Health Organization. Advice on the use of masks in the community, during home care, and in health care setting in the context of COVID-19. Geneva: World Health Organization; 2020

Yusuf, Muri. A. (2017). Metode Penelitian: Kuantitatif, Kualitatif, dan Penelitian Gabungan. Jakarta: Prenadamedia Group. 